\section{The Effect of Daily Light Integral, Ethephon, and Node Position of Impatiens $\times$ hybrida Stock Plants on Flowering of the Harvested Unrooted Cuttings}

\author{
Mary Vargo and James E. Faust \\ Plant and Environmental Sciences Department, Clemson University, \\ E-143 Poole Agriculture Center, Clemson, SC 29634
}

Additional index words. floriculture, greenhouse, sunpatiens

\begin{abstract}
Herbaceous stock plant production and cutting harvest methods affect the performance of cuttings harvested from those stock plants. Specifically, the effect of daily light integral (DLI), ethephon spray applications, and the stock plant node position $\left(\mathrm{NP}_{\mathrm{SP}}\right)$ of hybrid impatiens (Impatiens $\times$ hybrida) 'Compact Electric Orange' stock plants on the flowering of the harvested cuttings was examined. The DLI treatments were grouped in ranges of low $\left(5.1-5.5 \mathrm{~mol} \cdot \mathrm{m}^{-2} \cdot \mathrm{d}^{-1}\right)$, medium $(7.6-8.8$ mol $\left.\cdot \mathrm{m}^{-2} \cdot \mathrm{d}^{-1}\right)$, and high $\left(10.3-12.0 \mathrm{~mol} \cdot \mathrm{m}^{-2} \cdot \mathrm{d}^{-1}\right)$ levels. The stock plants were treated weekly with $0,50,100,200$, or $300 \mathrm{mg} \cdot \mathrm{L}^{-1}$ ethephon. Cuttings were harvested from six $\mathrm{NP}_{\mathrm{SP}}$, which refers to the location on the stock plants from which the cuttings were harvested. Time to flower of the harvested cuttings decreased as DLI increased from 5.1 to $12.0 \mathrm{~mol} \cdot \mathrm{m}^{-2} \cdot \mathrm{d}^{-1}$, as ethephon concentrations decreased from 300 to 0 $\mathrm{mg} \cdot \mathrm{L}^{-1}$, and as $\mathrm{NP}_{\mathrm{SP}}$ moved from lower to upper positions within the stock plant canopy. Time to flower was highly correlated with the node position on the cutting $\left(\mathbf{N P}_{\mathbf{C}}\right)$ where the first flower appeared. For example, when flowers appeared in the lowest $\mathrm{NP}_{\mathrm{C}}$ on the shoot $\left(\mathrm{NP}_{\mathrm{C}} \mathbf{1}\right)$, the first flower opened 2.5 weeks after sticking the unrooted cuttings in propagation, while flowers that appeared in $\mathrm{NP}_{\mathrm{C}} 7$, the seventh-oldest node from the base of the cutting, opened at 9.0 weeks. The results demonstrate how stock plant management practices can be manipulated to produce cuttings that allow growers to produce flowering plants on different schedules, i.e., production time can be shortened from conventional production schedules, which may allow hybrid impatiens to be marketed like bedding plant species such as impatiens (Impatiens walleriana).
\end{abstract}

The U.S. floriculture industry imports over 1 billion unrooted cuttings annually (U.S. Census Bureau, 2020) to propagate and grow to a flowering stage for the domestic market. Vegetative cuttings allow propagators to maintain true-to-type genetic stability and uniform growth and development, allowing for synchronization of plant production and increased automation (Druege, 2009). Vegetative cuttings are produced on wellbranched stock plants that are maintained in a

Received for publication 22 Dec. 2020. Accepted for publication 9 Mar. 2021.

Published online 30 April 2021.

This is Technical Contribution No. 6959 of the Clemson University Experiment Station. This material is based on work supported by the National Institute of Food and Agriculture/United States Department of Agriculture (USDA), under project number SC-1700585. Thanks to the USDA-Agricultural Research Service, Floriculture and Nursery Research Initiative for their financial support. J.E.F. is the corresponding author. E-mail: jfaust@ clemson.edu

This is an open access article distributed under the CC BY-NC-ND license (https://creativecommons. org/licenses/by-nc-nd/4.0/). vested on a weekly basis (Faust et al., 2016). The top three countries for exporting unrooted cuttings to the United States are Guatemala, Costa Rica, and Mexico, with reported annual U.S. custom values of $\$ 23$, $\$ 18$, and $\$ 14$ million (U.S.), respectively (U.S. Census Bureau, 2020).

The genus Impatiens includes several popular ornamental species valued in the floriculture industry for their highly decorative flowers and long blooming season. Bedding plant impatiens (Impatiens walleriana) have been a popular seed-propagated species since the 1970s, and new guinea impatiens (Impatiens hawkeri) have been a well-liked vegetatively propagated species since the 1980s (Dole and Wilkins, 2005). Hybrid impatiens (Impatiens $\times$ hybrida) were introduced in the 2000 s and are vegetatively propagated with flowers and foliage that resemble new guinea impatiens, but with improved landscape performance and higher tolerance to sunlight. SunPatiens ${ }^{\mathrm{TM}}$ is a trademarked series of hybrid impatiens with an annual wholesale market value of $\approx \$ 95 \mathrm{M}$ (M. Seguin, personal communication, 8 Mar. 2019). SunPatiens have grown in popularity due to their vegetative state so that shoots can be har- exceptional landscape performance and their resistance to impatiens downy mildew (Plasmopara obducens), which causes rapid defoliation of bedding plant impatiens in the landscape (Wegulo et al., 2004).

Two market challenges limit further growth of the hybrid impatiens market and their ability to compete with bedding plants in the landscape market. First, hybrid impatiens are larger plants than typical bedding plant species, so they are usually sold in larger containers at a higher price point. Second, hybrid impatiens have a longer production time than bedding plant impatiens, which also makes them comparatively more expensive to produce. Therefore, this project examines methods of growing stock plants to produce hybrid impatiens cuttings that can be grown in smaller, bedding plant-style containers and that flower on a faster schedule, potentially allowing hybrid impatiens to be more competitive in the landscape market.

Light management within the greenhouse environment is a critical factor for stock plant production that influences cutting yield and performance (Blanchard and Runkle, 2011; Tollenaar and Aguilera, 1992). A wide range of daily light integral (DLI) values occur throughout the year, e.g., from 5 to $60 \mathrm{~mol} \cdot \mathrm{m}^{-2} \cdot \mathrm{d}^{-1}$ outdoors and from 1 to $25 \mathrm{~mol} \cdot \mathrm{m}^{-2} \cdot \mathrm{d}^{-1}$ inside greenhouses (Faust and Logan, 2018). Providing the desired DLI to specific crops can be achieved with supplemental lighting, retractable roofs, and/or retractable shade curtains. In stock plant production, DLI affects branching and thus the number of cuttings harvested from each stock plant (Glady et al., 2007). For example, Donnelly and Fisher (2002) reported a 73\% increase in the total number of viable cuttings harvested from fan flower (Scaevola aemula) stock plants when supplemental lighting from high-pressure sodium lamps delivered a DLI of $2.8 \mathrm{~mol} \cdot \mathrm{m}^{-2} \cdot \mathrm{d}^{-1}$ in addition to the ambient DLI of $6.2 \mathrm{~mol} \cdot \mathrm{m}^{-2} \cdot \mathrm{d}^{-1}$. Increases in cutting stem diameter and cutting yield have been observed for stock plants of bacopa (Jamesbrittenia grandiflora), heliotrope (Heliotropium arborescens), and thunbergia (Thunbergia alata) as DLI increased from 4 to $14 \mathrm{~mol} \cdot \mathrm{m}^{-2} \cdot \mathrm{d}^{-1}$ (Lopez, 2007).

Prolific flowering is a desirable market trait selected for by ornamental plant breeders; however, the presence of flowers on stock plants poses a cutting production challenge due to reductions in cutting yield (Faust and Lewis, 2005). Floral development on stock plants can be inhibited or delayed with the application of ethephon [(2-chloroethyl) phosphonic acid] (Latimer and Whipker, 2013). Ethephon delays flowering in many species when they are treated with rates of $250-1000 \mathrm{mg} \cdot \mathrm{L}^{-1}$. For example, two applications of 250 to $1000 \mathrm{mg} \cdot \mathrm{L}^{-1}$ ethephon delays flowering of streptocarpus (Streptocarpus $\times$ hybrida) by 20 to $39 \mathrm{~d}$, respectively (Currey and Flax, 2015). Continuous weekly applications of ethephon can completely inhibit flowering until applications cease. 
Cuttings are harvested from the uppermost part of the stock plant. The specific $\mathrm{NP}_{\mathrm{SP}}$ from which the lateral shoots emerge affects the shoot's vegetative or reproductive nature (Faust and Grimes, 2005). In a study with nemesia (Nemesia fruticans), $\mathrm{NP}_{\mathrm{SP}}$ determines the number of nodes formed on the lateral shoot before the terminal flower appears (Faust and Grimes, 2004). For example, lateral shoots from higher $\mathrm{NP}_{\mathrm{SP}}$ develop fewer nodes before flowering. Thus, cuttings harvested from lower $\mathrm{NP}_{\mathrm{SP}}$ were more vegetative and flowered at a later date. Harvesting a more vegetative shoot is typically a desirable option because the vegetative shoot does not prematurely initiate flowers in propagation.

In this study, stock plant management techniques and $\mathrm{NP}_{\mathrm{SP}}$ of the harvested cuttings were explored on hybrid impatiens for the purpose of producing unrooted cuttings that flowered on a predictable schedule. Specifically, DLI, ethephon application rates, and $\mathrm{NP}_{\mathrm{SP}}$ treatments provided to stock plants were examined for their effect on the flowering of harvested cuttings. The results provide stock plant growers with useful strategies for producing cuttings that have a more predictable flowering schedule.

\section{Materials and Methods}

Two hundred sixteen hybrid impatiens 'Compact Electric Orange' plants were grown as stock plants for 8 weeks. During this time, the stock plants received three DLI and five ethephon treatments. Cuttings were removed from six different node positions on the stock plants, defined as the $\mathrm{NP}_{\mathrm{SP}}$ treatments. The harvested cuttings were propagated and grown to flower. The experiment was conducted twice over time. Bedding plant impatiens and new guinea impatiens are day-neutral with respect to flowering (Arisumi and Cathey, 1976), so the different photoperiods provided during the experiments would not affect flowering. The DLI, ethephon, and NP treatments are described in the following section.

DLI treatments. Three DLI environments were created using three benches $(7.3 \mathrm{~m} \times 1.5$ $\mathrm{m})$ in one greenhouse that were each subdivided into three sections $(7.3 \mathrm{~m} \times 1.5 \mathrm{~m} \times 0.9$ m) separated with aluminized radiant barriers (Double Reflective Insulation; Reflectix Inc., Markleville, IN). Twenty-four plants were placed in each of the nine bench sections. Shadecloth was positioned over one-third of the sections to provide a $55 \%$ reduction in the photosynthetic photon flux density (PPFD) (Tempa Climate Screen; Ludwig Svensson, Charlotte, NC), while one-third of the sections were shaded with $30 \%$ PPFD-reduction shadecloth (Green-Tek Inc., Dinuba, CA). The remaining one-third of the sections received the ambient PPFD. The three DLI sections were randomized on each of three benches. Line quantum sensors (SQ-316-SS; Apogee Instruments, Logan, UT) were placed immediately above the stock plant canopy in one of each of the DLI environments to measure $P P F D$ every $10 \mathrm{~s}$ while recording 15 -min averages with a data logger (CR206X; Campbell Scientific, Logan, UT). The mean DLI for each of the three treatments over the course of the first replication of the experiment was $5.5 \pm 1.3,8.8 \pm$ 1.4 , and $12.0 \pm 1.4 \mathrm{~mol} \cdot \mathrm{m}^{-2} \cdot \mathrm{d}^{-1}$. The mean DLI provided for each of the three treatments during the second replication of the experiment was $5.1 \pm 1.3,7.6 \pm 1.5$, and $10.3 \pm 1.5$ $\mathrm{mol} \cdot \mathrm{m}^{-2} \cdot \mathrm{d}^{-1}$. The lowest, middle, and highest DLI treatments provided during each of the two replications are referred to as the low, medium, and high DLI treatments.

Ethephon treatments. In replication 1 of this experiment, six stock plants within each DLI treatment received weekly spray applications of $0,100,200$, or $300 \mathrm{mg} \cdot \mathrm{L}^{-1}$ ethephon and a surfactant $\left(0.4 \mathrm{~mL} \cdot \mathrm{L}^{-1}\right.$ Capsil; Aquatrols, Paulsboro, NJ) with a hand sprayer at a rate of $137 \mathrm{~mL} \cdot \mathrm{m}^{-2}$ between 0700 and 0800 HR. Ethephon concentrations were adjusted in the second replication of this experiment replacing $100 \mathrm{mg} \cdot \mathrm{L}^{-1}$ ethephon with 50 $\mathrm{mg} \cdot \mathrm{L}^{-1}$ resulting in ethephon concentrations of $0,50,100$, or $300 \mathrm{mg} \cdot \mathrm{L}^{-1}$. This change was handled as an additional treatment level to the experiment, resulting in a total of five ethephon rates to be investigated. The ethephon treatments were applied once per week for 8 weeks.

$N P_{S P}$ treatments. The primary shoot of the stock plant was pinched to three nodes at the start of the experiment, and the secondary shoots emerged from leaf axils of the remaining nodes (Fig. 1). After four nodes developed on the secondary shoot, the shoot was pinched below the fourth node, leaving three nodes behind, and the tertiary

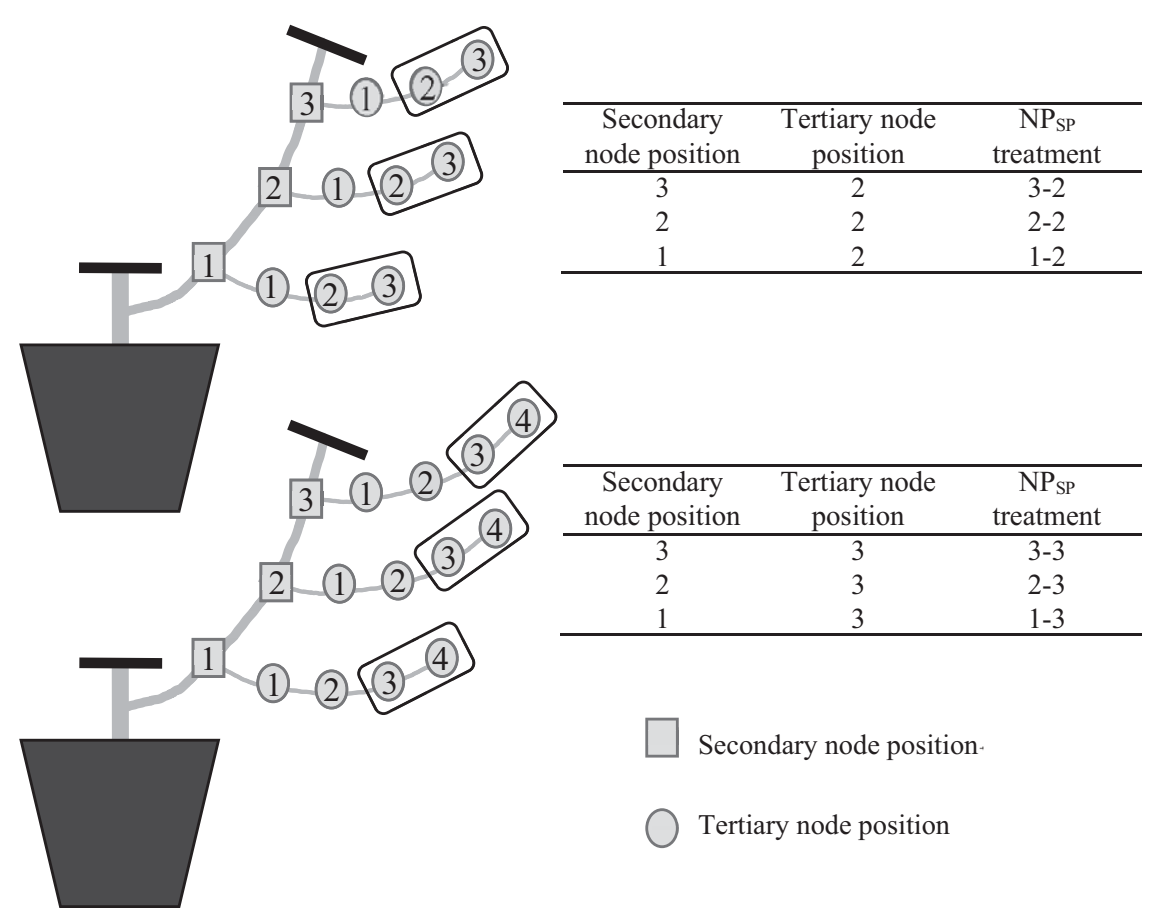

Fig. 1. Diagram describing the six stock plant node positions $\left(\mathrm{NP}_{\mathrm{SP}}\right)$ treatments. The numbered squares identify the secondary $\mathrm{NP}_{\mathrm{SP}}$, and numbered circles identify the tertiary $\mathrm{NP}_{\mathrm{SP}}$. The $\mathrm{NP}_{\mathrm{SP}}$ treatments are described by the secondary $\mathrm{NP}_{\mathrm{SP}}$ from which the shoot originated and the lowest of the two tertiary $\mathrm{NP}_{\mathrm{SP}}$ visible on the cutting. shoots emerged from the leaf axils of the remaining nodes. Cuttings were harvested from the tertiary shoots once the appropriate number of nodes had developed, and the harvested cuttings were identified by the secondary and tertiary $\mathrm{NP}_{\mathrm{SP}}$ from which they developed. For example, each cutting developed from one of three secondary $\mathrm{NP}_{\mathrm{SP}}$, and each cutting possessed two visible tertiary nodes of which the lowest $\mathrm{NP}_{\mathrm{SP}}$ was recorded. Therefore, the numbering system for the cuttings consisted of a secondary $\mathrm{NP}_{\mathrm{SP}}(1,2$, or 3$)$ and a tertiary $\mathrm{NP}_{\mathrm{SP}}$ (2 or 3 ). The result was that $\mathrm{NP}_{\mathrm{SP}}$ treatments consisted of six combinations of the secondary and tertiary node positions as follows: $1-2,2-2,3-2,1-3,2-3$, or $3-3$, where the first number is the secondary $\mathrm{NP}_{\mathrm{SP}}$ from which the shoot originated and the second number is the lowest of the two tertiary $\mathrm{NP}_{\mathrm{SP}}$ on the cutting. Note that on commercial stock plants, one to two nodes are typically left remaining on a stock plant stem from which a cutting is removed to allow for future shoot and cutting production.

Data collection. Cuttings were harvested as they reached the appropriate node positions, which occurred from the third to the eighth week of the DLI $\times$ ethephon treatments. The harvested cuttings were propagated and grown until the first flower appeared on each plant. The node positions on cuttings $\left(\mathrm{NP}_{\mathrm{C}}\right)$ were numbered from bottom to top, starting with the lowest node as 1. The lowest node on the harvested cutting was positioned at the top of the propagation medium so that all nodes were visible throughout the experiment. The $\mathrm{NP}_{\mathrm{C}}$ where the first open flower 
appeared was recorded for each plant, as was the date of first open flower. Branching of the flowering plants was quantified by counting the number of axillary shoots $>2 \mathrm{~cm}$ long emerging from the primary stem 10 weeks after the cuttings were harvested and stuck in propagation.

Plant culture. Two replications of the experiment were conducted in two consecutive growing seasons: summer and fall of 2019. Stock plants were grown in 1.33 -L containers with a peat-based growing medium (Fafard 3B; Sun Gro, Anderson, SC). A constant liquid fertigation program using Peter's Excel CalMag Special $(15 \mathrm{~N}-2.2 \mathrm{P}-12.5 \mathrm{~K}-5 \mathrm{Ca}-2 \mathrm{Mg}$; Scotts-Sierra, Marysville, $\mathrm{OH}$ ) provided 150 $\mathrm{mg} \cdot \mathrm{L}^{-1} \mathrm{~N}$ every other week, while water was applied as needed. The cuttings harvested from the various treatments were propagated in 105cell trays with a peat-based propagation medium (Sunshine Redi-Earth; Sun Gro, Anderson, SC) for 2 weeks and transplanted to six-pack trays (6 cells/container, $145 \mathrm{~mL} /$ cell) filled with the same peat-based medium used for the stock plants. Fertilization of the cuttings occurred every other week, delivering 200 $\mathrm{mg} \cdot \mathrm{L}^{-1} \mathrm{~N}$ with Peter's Excel Cal-Mag Special at each fertigation event. In the stock plant environment, the average daily temperatures were $24.5 \pm 2.4$ and $24.0 \pm 2.1^{\circ} \mathrm{C}$ for replications 1 and 2, respectively. During the flowering phase, the average daily temperatures were $24.3 \pm 2.3$ and $20.8 \pm 2.6^{\circ} \mathrm{C}$ for replications 1 and 2 , respectively.

Experimental design and data analysis. The experimental design was a split-split plot arrangement with a factorial treatment structure. The factors investigated were three levels of the whole plot factor (DLI), five levels of the subplot factor (ethephon), and six levels of the sub-subplot factor $\left(\mathrm{NP}_{\mathrm{SP}}\right)$. The DLI treatments were randomly assigned to each of three greenhouse benches. Ethephon treatments were randomly assigned to the stock plants within each DLI treatments. Each stock plant produced two cuttings from each of the six $\mathrm{NP}_{\mathrm{SP}}$ treatments for a total of 12 cuttings harvested per stock plant. Analysis of variance was performed using JMP Pro version 13.2.0 (SAS Institute Inc, Cary, NC).

\section{Results and Discussion}

Time to flower was affected by the significant interaction between ethephon, DLI, and $\mathrm{NP}_{\mathrm{SP}}$ (Table 1). In general, low ethephon concentrations have a greater effect on flowering at the low and medium DLI levels compared with high DLI level (Fig. 2). High concentrations of ethephon have a strong effect on flowering across all DLI treatments when cuttings are harvested from low $\mathrm{NP}_{\mathrm{SP}}$, while the effect of ethephon is dampened on cuttings harvested from high DLI environments and high $\mathrm{NP}_{\mathrm{SP}}$.

The significant three-way interaction between DLI, ethephon, and $\mathrm{NP}_{\mathrm{SP}}$ can be understood by first considering the individual effect of each of these factors on flowering. First, high DLI promotes flowering because of the increased availability of carbohydrates to support reproductive development, although hybrid impatiens have a relatively low DLI requirement for flowering. Second, ethephon inhibits flowering by causing the abortion of existing floral structures. Third, flowering is more likely to occur with each additional node that develops within the stock plant canopy, i.e., nodes in higher $\mathrm{NP}_{\mathrm{SP}}$ are more likely to differentiate flower primordia in the leaf axil, while the lower $\mathrm{NP}_{\mathrm{SP}}$ are more likely to differentiate vegetative primordia that will contribute to increased branching, leaf area, and light interception (Faust and Grimes, 2005). Therefore, when no ethephon was applied to the stock plant, flowering of the cutting occurred rapidly even if the DLI was relatively low, so flowers initiated and developed in lower $\mathrm{NP}_{\mathrm{SP}}$, and time to flower was relatively fast. As ethephon rates were increased from 50 to $200 \mathrm{mg} \cdot \mathrm{L}^{-1}$, flowering was delayed, and the magnitude of the delay was greater at the low DLI and at the lower $\mathrm{NP}_{\text {SP. }}$ When the flowering signal was stronger, e.g., high DLI and high $\mathrm{NP}_{\mathrm{SP}}$, the effect of ethephon is dampened, so higher concentrations are required to inhibit flowering. For example, as ethephon concentrations were increased from 200 to 300 $\mathrm{mg} \cdot \mathrm{L}^{-1}$, flowering was completely inhibited at the entire range of DLI treatments provided in this study when considering cuttings harvested from low NP $\mathrm{SP}_{\mathrm{SP}}$. However, at the highest $\mathrm{NP}_{\mathrm{SP}}$ and the high DLI treatment, the highest ethephon rate $(300$ $\mathrm{mg} \cdot \mathrm{L}^{-1}$ ) did not create an entirely vegetative cutting. Thus, when high concentrations of ethephon (300 $\mathrm{mg} \cdot \mathrm{L}^{-1}$ ethephon) were applied, flowering occurred 1-2 weeks faster on cuttings coming from the high DLI and high $\mathrm{NP}_{\mathrm{SP}}$ treatments compared with the low DLI and low $\mathrm{NP}_{\mathrm{SP}}$ treatments. The $300 \mathrm{mg} \cdot \mathrm{L}^{-1}$ ethephon treatment produces a fully vegetative cutting at the low DLI and low $\mathrm{NP}_{\mathrm{SP}}$ treatments, i.e., a cutting that requires the maximum time to flower $(\approx 9$ weeks $)$.

The $\mathrm{NP}_{\mathrm{C}}$ of the first open flower responded to the ethephon, DLI, and $\mathrm{NP}_{\mathrm{SP}}$ treatments in a very similar pattern as the time to flower data, such that the 3-way interaction of these factors was also significant (Table 1, Fig. 3). This is logical because each node takes $\approx 7-9 \mathrm{~d}$ to develop at the temperatures used in this study, thus plants that flowered at higher $\mathrm{NP}_{\mathrm{C}}$ also flowered at a later date. Stock plants treated with the $0 \mathrm{mg} \cdot \mathrm{L}^{-1}$ ethephon typically developed the first flower in $\mathrm{NP}_{\mathrm{C}}$ 1-2 regardless of DLI. As ethephon concentrations increased from 50 to 200 $\mathrm{mg} \cdot \mathrm{L}^{-1}$, the $\mathrm{NP}_{\mathrm{C}}$ of the first open flower increased from 2 to 6 , and low to medium DLI treatments flowered about one higher $\mathrm{NP}_{\mathrm{C}}$ compared with the high DLI treatments. At the highest ethephon treatment $\left(300 \mathrm{mg} \cdot \mathrm{L}^{-1)}\right.$, differences in responses to DLI varied with $\mathrm{NP}_{\mathrm{SP}}$, e.g., the difference between DLI treatments were only observed at the higher $\mathrm{NP}_{\mathrm{SP}}$ (3-2, 2-3, and 3-3).

Figure 4 demonstrates the relationship between the two flowering responses presented in Figs. 2 and 3, where time to flower increased as $\mathrm{NP}_{\mathrm{C}}$ increased. Plants that flowered in $<4$ weeks were associated with the first flower appearing in the two bottommost $\mathrm{NP}_{\mathrm{C}}$. Cuttings that were completely vegetative at the time of harvest produced their first flower in $\mathrm{NP}_{\mathrm{C}}$ 6-9, which opened 9 to 10 weeks after cutting harvest.

The number of axillary shoots formed 10 weeks after the cuttings were harvested was most affected by the ethephon treatments (Table 1). For example, the number of axillary shoots increased from 1.4 to 5.2 as

Table 1. Analysis of variance for the effect of daily light integral (DLI), ethephon, and node positions on the stock plants $\left(\mathrm{NP}_{\mathrm{SP}}\right)$ on time to flower, node position of the first flower on the cutting $\left(\mathrm{NP}_{\mathrm{C}}\right)$, and the number of axillary shoots formed 10 weeks after the start of propagation of hybrid impatiens 'Compact Electric Orange'.

\begin{tabular}{|c|c|c|c|c|}
\hline Response & Factor & $F$-ratio & Significance & $P$ value \\
\hline \multirow[t]{7}{*}{ Time to flower } & $\overline{D L I}$ & 77.4 & $* * *$ & $<0.0001$ \\
\hline & Ethephon & 1404.5 & $* * *$ & $<0.0001$ \\
\hline & $\mathrm{NP}_{\mathrm{SP}}$ & 87.8 & $* * *$ & $<0.0001$ \\
\hline & DLI $\times$ Ethephon & 27.2 & $* * *$ & $<0.0001$ \\
\hline & $\mathrm{DLI} \times \mathrm{NP}_{\mathrm{SP}}$ & 2.3 & * & 0.0108 \\
\hline & Ethephon $\times \mathrm{NP}_{\mathrm{SP}}$ & 13.4 & $* * *$ & $<0.0001$ \\
\hline & DLI $\times$ Ethephon $\times \mathrm{NP}_{\mathrm{SP}}$ & 1.8 & $* *$ & 0.0018 \\
\hline \multirow{7}{*}{$\mathrm{NP}_{\mathrm{C}}$} & DLI & 29.8 & ** & 0.0006 \\
\hline & Ethephon & 1810.4 & $* * *$ & $<0.0001$ \\
\hline & $\mathrm{NP}_{\mathrm{SP}}$ & 103.8 & $* * *$ & $<0.0001$ \\
\hline & DLI $\times$ Ethephon & 17.1 & $* * *$ & $<0.0001$ \\
\hline & $\mathrm{DLI} \times \mathrm{NP}_{\mathrm{SP}}$ & 1.4 & NS & 0.1673 \\
\hline & Ethephon $\times \mathrm{NP}_{\mathrm{SP}}$ & 6.2 & $* * *$ & $<0.0001$ \\
\hline & $\mathrm{DLI} \times$ Ethephon $\times \mathrm{NP}_{\mathrm{SP}}$ & 2.3 & $* * *$ & $<0.0001$ \\
\hline \multirow[t]{7}{*}{ Number of axillary shoots } & DLI & 48.0 & $* * *$ & $<0.0001$ \\
\hline & Ethephon & 805.4 & $* * *$ & $<0.0001$ \\
\hline & $\mathrm{NP}_{\mathrm{SP}}$ & 13.7 & $* * *$ & $<0.0001$ \\
\hline & DLI $\times$ Ethephon & 7.4 & $* * *$ & $<0.0001$ \\
\hline & $\mathrm{DLI} \times \mathrm{NP}_{\mathrm{SP}}$ & 2.2 & $*$ & 0.0153 \\
\hline & Ethephon $\times \mathrm{NP}_{\mathrm{SP}}$ & 8.5 & $* * *$ & $<0.0001$ \\
\hline & DLI $\times$ Ethephon $\times \mathrm{NP}_{\mathrm{SP}}$ & 1.9 & $* *$ & 0.0008 \\
\hline
\end{tabular}

NS, ${ }^{*}, * *, * *$ Nonsignificant or significant at $P<0.05,0.01$, or 0.001 , respectively 


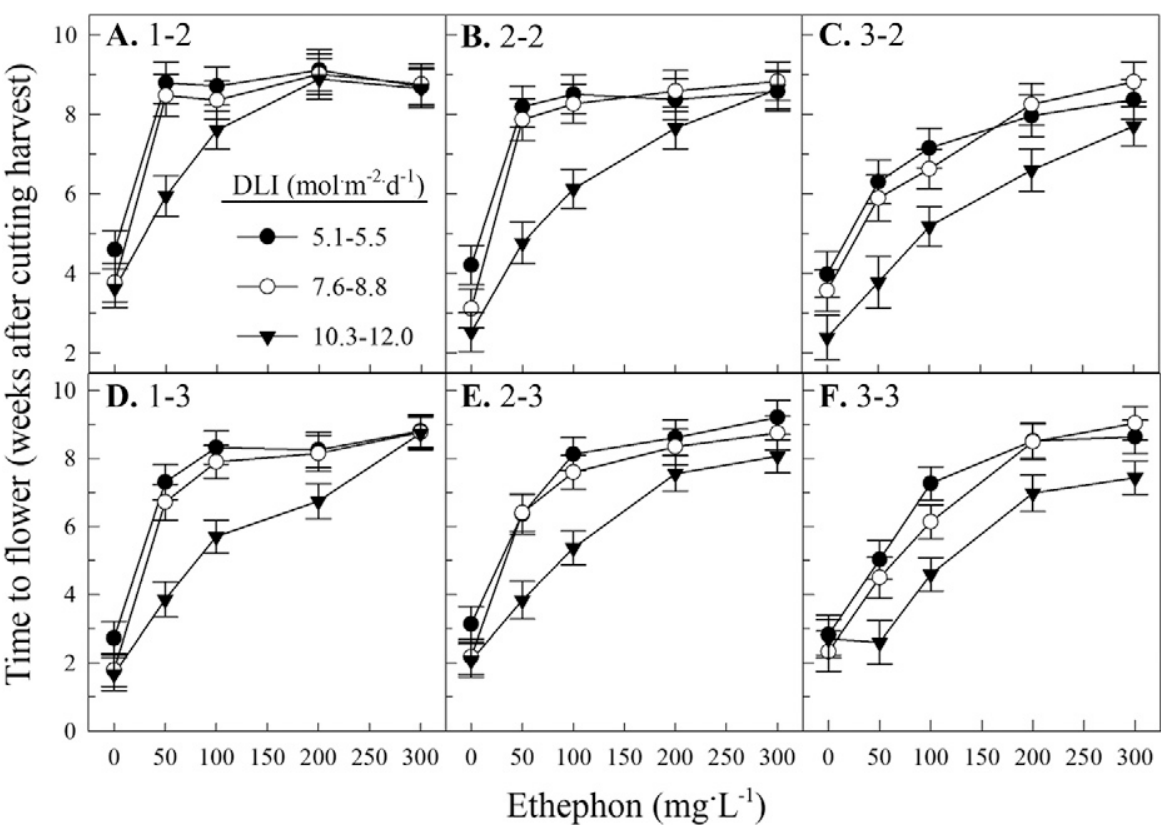

Fig. 2. The interaction of ethephon, daily light integral (DLI), and stock plant node position $\left(\mathrm{NP}_{\mathrm{SP}}\right)$ treatments applied to hybrid impatiens 'Compact Electric Orange' stock plants on time to flower of the harvested cuttings. The DLIs from experimental replications one and two are grouped together into their respective low, medium, and high levels. Weekly ethephon applications were made to stock plants for 8 weeks. Cuttings were harvested at six $\mathrm{NP}_{\mathrm{SP}}$ treatments, which refers to the position of the cutting within the stock plant canopy. The $\mathrm{NP}_{\mathrm{SP}}$ treatment is shown in the upper left of each figure, where the first number identifies the secondary $\mathrm{NP}_{\mathrm{SP}}$ and the second number identifies the lowest tertiary $\mathrm{NP}_{\mathrm{SP}}$ on the cutting. Vertical bars represent $\pm 1 \mathrm{SE}(\mathrm{n}=12$ for ethephon rates of 50 and $200 \mathrm{mg} \cdot \mathrm{L}^{-1}$ and $\mathrm{n}=24$ for ethephon rates of 0,100 , and $300 \mathrm{mg} \cdot \mathrm{L}^{-1}$ ).

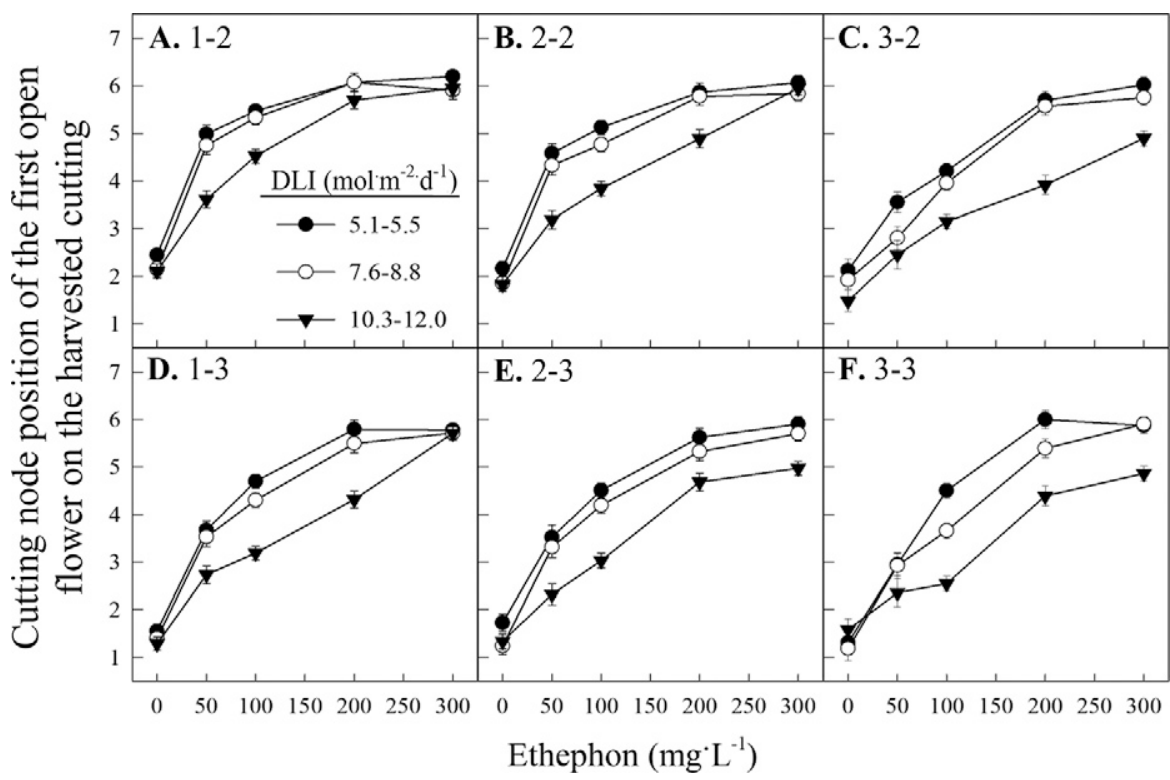

Fig. 3. The interaction of ethephon, daily light integral (DLI), and stock plant node position $\left(\mathrm{NP}_{\mathrm{SP}}\right)$ treatments applied to hybrid impatiens 'Compact Electric Orange' stock plants on the cutting node position $\left(\mathrm{NP}_{\mathrm{C}}\right)$ of the first open flower appearing on the harvested cuttings. The DLIs from experimental replications one and two are grouped together into their respective low, medium, and high levels. Weekly ethephon applications were made to stock plants for 8 weeks. Cuttings were harvested at various $\mathrm{NP}_{\mathrm{SP}}$, which refers to the position of the cutting within the stock plant canopy. The $\mathrm{NP}_{\mathrm{SP}}$ is shown in the upper left of each figure, where the first number identifies the secondary $\mathrm{NP}_{\mathrm{SP}}$ and the second number identifies the lowest tertiary $\mathrm{NP}_{\mathrm{SP}}$ on the cutting. Vertical bars represent $\pm 1 \mathrm{SE}(\mathrm{n}=12$ for ethephon rates of 50 and $200 \mathrm{mg} \cdot \mathrm{L}^{-1}$ and $\mathrm{n}=24$ for ethephon rates of 0,100 , and $300 \mathrm{mg} \cdot \mathrm{L}^{-1}$ ).

ethephon increased from 0 to $300 \mathrm{mg} \cdot \mathrm{L}^{-1}$ (Fig. 5). The number of axillary shoots decreased as DLI levels increased, with a larger decrease occurring when DLI increased from the medium to the high level, e.g., the number of axillary shoots decreased from 4.0 to 3.4 as DLI increased from the medium to high level. The interaction between DLI and ethephon was most apparent at low levels of ethephon. In general, branching was more frequently observed at the low and medium levels of DLI when ethephon concentrations were between 0 to $200 \mathrm{mg} \cdot \mathrm{L}^{-1}$. As ethephon increased to $300 \mathrm{mg} \cdot \mathrm{L}^{-1}$, low, medium, and high DLI levels had a similar number of axillary shoots. For the main effect of $\mathrm{NP}_{\mathrm{SP}}$, axillary shoot number increased from 3.6 to 4.1 as $\mathrm{NP}_{\mathrm{SP}}$ decreased from 3 to 3 to $1-2$.

Flower development on stock plants is undesirable; therefore, hybrid impatiens stock plant growers typically provide a relatively low DLI to the stock plants and/or apply ethephon to produce vegetative cuttings. However, completely vegetative cuttings require a relatively long time to flower ( $\approx 9$ weeks). The present study demonstrates how stock plant management practices influence the time to flower of the harvested cuttings and thus provides guidance for how to manage stock plants to manipulate flowering time of the harvested impatiens cuttings. For the finished plant grower, reducing the time to flower from 8 to 5 weeks allows one to finish three crops during a 4-month spring season rather than just two crops. Such changes have tremendous economic implications.

Across all DLI and $\mathrm{NP}_{\mathrm{SP}}$ treatments, cuttings flowered from 2 to 9 weeks after sticking, depending on the concentration of ethephon applied. Thus, a strategy for stock plant growers may be 1) to provide a DLI of $10-12 \mathrm{~mol} \cdot \mathrm{m}^{-2} \cdot \mathrm{d}^{-1}$ to the stock plants, because this method will provide high cutting yield and quality (Lopez, 2007); and 2) to choose an appropriate concentration of ethephon to produce cuttings that will flower at a desired time. For example, high concentrations of ethephon can be applied to the stock plants if vegetative cuttings are desired; but if faster flowering of the harvested cuttings is desirable, then lower concentrations of ethephon can be applied.

One concern about growing stock plants under low ethephon application concentrations and high DLI is that more highly reproductive cuttings may not have enough vegetative nodes to create a high-quality landscape plant. Because impatiens flowers appear in leaf axils, vegetative lateral shoots are the source of future flowers in the landscape. Rapid-flowering plants in the greenhouse could potentially create an inferior plant for the consumer by limiting the nodes having potential to form additional lateral shoots and subsequent flowers. Our observations are that two vegetative shoots per plant are sufficient for providing adequate posttransplant growth, and our results suggest that a minimum of $50 \mathrm{mg} \cdot \mathrm{L}^{-1}$ ethephon needs to be applied to the stock plants to produce at least two vegetative shoots per plant. Thus, insufficient branching of the finished plant is a legitimate concern if ethephon is eliminated during stock plant production.

Node position of the harvested cutting affects flowering of that cutting; however, it is not realistic that the node position of every harvested cutting can be tightly managed during stock plant production due to the 


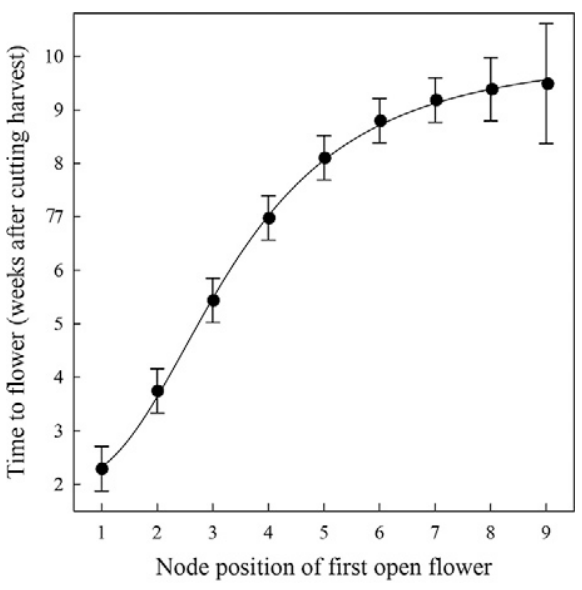

Fig. 4. Relationship between time to first open flower and the cutting node position $\left(\mathrm{NP}_{\mathrm{C}}\right)$ associated with the first open flower of hybrid impatiens 'Compact Electric Orange'. Node position of the first open flower was identified by numbering the nodes formed from the growing medium upwards on the primary stem, where the node positioned at the media surface was 1. Each data point represents a calculated mean value across all DLI, ethephon, and stock plant node position treatments, and the vertical bars represent the standard error associated with those means.

economic need for rapid harvesting. In our study, the variation from the lowest to the highest $\mathrm{NP}_{\mathrm{SP}}$ was relatively small compared to accurately control $\mathrm{NP}_{\mathrm{SP}}$ of the harvested with the ethephon response; thus, the inability

cuttings should not limit the stock plant grower from producing cuttings with predictable flowering schedules. Similar responses of time to flower on the $\mathrm{NP}_{\mathrm{SP}}$ have been demonstrated on other species. For example, in a study using miniature rose (Rosa hybrida), cuttings were harvested at low, medium, and high positions within the stock plant canopy. The high $\mathrm{NP}_{\mathrm{SP}}$ cuttings showed the fastest floral development (Bredmose et al., 2004). A study on the influence of the physiological maturity $(3,6,9$, or 12 nodes) and the cutting location on the stock plant (top-half canopy or bottom-half canopy) from statice (Limonium) stock plants showed that mature, tophalf canopy cuttings with 9-12 nodes take the shortest time to flower and have the least variation in flowering time (Funnell et al., 2003).

The use of greenhouse space in commercial operations must be optimized to maintain profitability (Will et al., 1999; Whipker and McCall, 2000); thus, crops that flower rapidly and uniformly allow the greenhouse space to be re-planted and additional crops grown Hence, producing cuttings that flower in a shortened schedule has considerable commercial appeal. The results of this study provide guidance to stock plant growers toward methods of producing stock plants and harvesting cuttings that allow propagator-growers to more closely control flowering whether it be for faster or slower flowering.

Faster-flowering crops can be finished in smaller containers that are more appropriate for the landscape market. This would allow

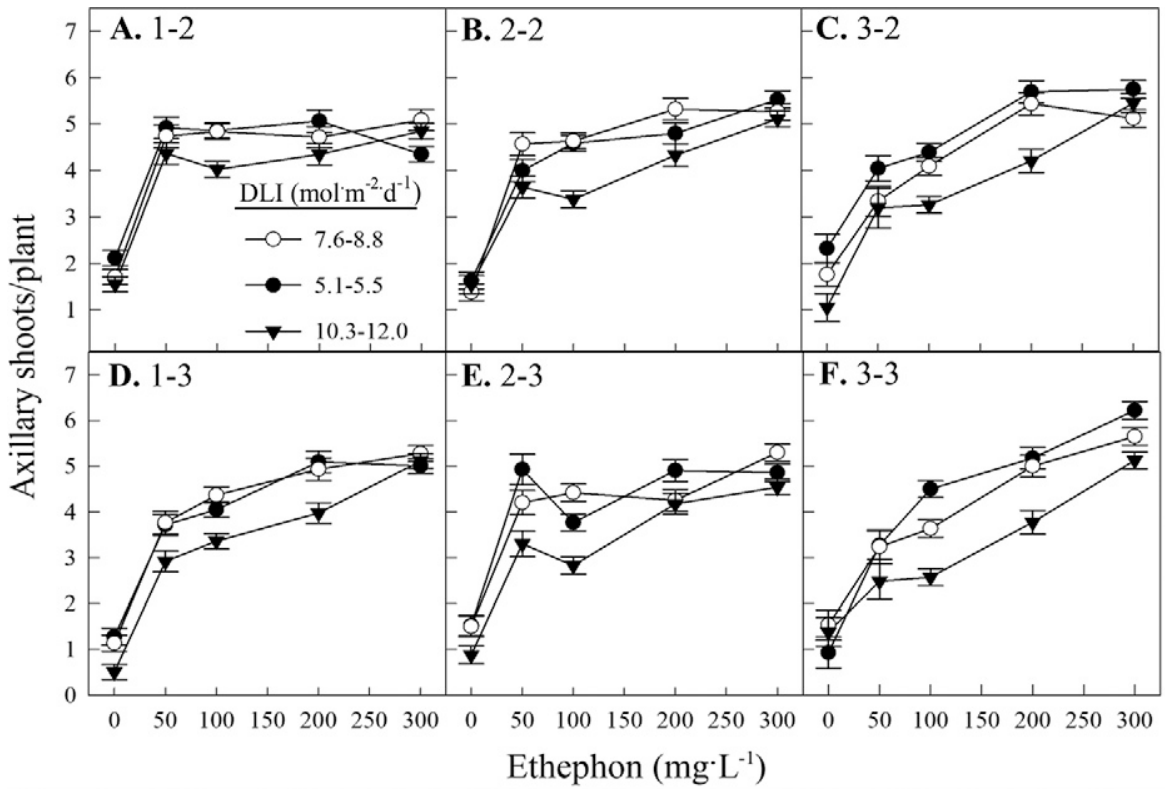

Fig. 5. The interaction of ethephon, daily light integral (DLI), and stock plant node position $\left(\mathrm{NP}_{\mathrm{SP}}\right)$ treatments applied to hybrid impatiens 'Compact Electric Orange' stock plants on the number of axillary shoots emerging from the primary stem at 10 weeks after cutting harvest. The DLIs from experimental replications one and two are grouped together into their respective low, medium, and high levels. Weekly ethephon applications were made to stock plants for 8 weeks. Cuttings were harvested at various $\mathrm{NP}_{\mathrm{SP}}$, which refers to the position of the cutting within the stock plant canopy. The $\mathrm{NP}_{\mathrm{SP}}$ is shown in the upper left corner of each figure; the first number identifies the secondary $\mathrm{NP}_{\mathrm{SP}}$ and the second number identifies the lowest tertiary $\mathrm{NP}_{\mathrm{SP}}$ on the cutting. Vertical bars represent \pm 1 SE ( $n=12$ for ethephon rates of 50 and $200 \mathrm{mg} \cdot \mathrm{L}^{-1}$ and $\mathrm{n}=24$ for ethephon rates of 0,100 , and $\left.300 \mathrm{mg} \cdot \mathrm{L}^{-1}\right)$. hybrid impatiens to be produced and sold in multiunit packs, like bedding plants. The established market for hybrid impatiens has been for larger plants grown in individual containers that take a longer time to flower, so these results may allow for the development of hybrid impatiens as a high-volume bedding plant.

In conclusion, a predictable flowering time for a hybrid impatiens cutting from the time of cutting harvest to first open flower can be achieved by controlling factors within the stock plant environment. Ethephon and DLI can be managed to provide cuttings that flower on various schedules suitable to the propagator/grower.

\section{Literature Cited}

Arisumi, T. and H.M. Cathey. 1976. The New Guinea impatiens. HortScience 11:2.

Blanchard, M.G. and E.S. Runkle 2011. Quantifying the thermal flowering rates of eighteen species of annual bedding plants. Sci. Hort. 128: 30-37, doi: 10.1016/j.scienta.2010.12.010

Bredmose, N., K. Kristiansen, and B. Nielsen. 2004. Propagation temperature, PPFD, auxin treatment, cutting size and cutting position affect root formation, axillary bud growth and shoot development in miniature rose (Rosa hybrida L.) plants and alter homogeneity. J. Hort. Sci. Biotechnol. 79:458-465, doi: 10.1080/146 20316.2004.11511790.

Currey, C.J. and N.J. Flax. 2015. Ethephon foliar sprays prevent premature flowering of tissue culture-propagated Streptocarpus hybrids. HortTechnology 25:635-638, doi: 10.21273/horttech. 25.5.635.

Dole, J.M. and H.F. Wilkins. 2005. Floriculture: Principles and species. 2nd ed. Pearson Education, London, UK.

Donnelly, C.S. and P.R. Fisher. 2002. High-pressure sodium lighting affects greenhouse production of vegetative cuttings for specialty annuals. HortScience 37:623-626, doi: 10.212 73/hortsci.37.4.623.

Druege, U. 2009. Involvement of carbohydrates in survival and adventitious root formation of cuttings within the scope of global horticulture, p. 187-208. In: K. Niemi and C.F. Scagel (eds.). Adventitious root formation of forest trees and horticultural plants-From genes to applications. Research Signpost, Kerala, India.

Faust, J.E., J.M. Dole, and R.G. Lopez. 2016. The floriculture vegetative cutting industry. Hort. Rev. 44:121-172, doi: 10.1002/97811192812 69.ch3.

Faust, J.E. and L.W. Grimes. 2004. Cutting production is affected by pinch number during scaffold development of stock plants. HortScience 39:1691-1694, doi: 10.21273/ hortsci.39.7.1691.

Faust, J.E. and L.W. Grimes. 2005. Pinch height of stock plants during scaffold development affects cutting production. HortScience 40:650-653, doi: 10.21273/hortsci.40.3.650

Faust, J.E. and K.P. Lewis. 2005. Modeling flower bud development of Impatiens hawkeri and I. walleriana. HortScience 40:1013, doi: 10.21273/ hortsci.40.4.1013a.

Faust, J. and J. Logan. 2018. Daily light integral: A research review and high resolution maps of the United States. HortScience 53: 1250-1257, doi: 10.21273/hortsci13144-18.

Funnell, K.A., M. Bendall, W.F. Fountain, and E.R. Morgan. 2003. Maturity and type of 
cutting influences flower yield, flowering time, and quality in Limonium 'Chorus Magenta'. New Zeal. J. Crop Hort. 31:139-146, doi: $10.1080 / 01140671.2003 .9514246$.

Glady, J.E., N.S. Lang, and E.S. Runkle. 2007. Effects of ethephon on stock plant management of Coreopsis verticillata, Dianthus caryophyllus, and Veronica longifolia. HortScience 42:16161621, doi: 10.21273/hortsci.42.7.1616.

Latimer, J.G. and Whipker, B. 2013. Selecting and using plant growth regulators on floricultural crops. Publ. 430-102. Virginia Coop. Ext., Blacksburg, VA.
Lopez, R.G. 2007. Stock plant and propagation photosynthetic daily light integral and storage influence postharvest performance of herbaceous cuttings. Michigan State University, Department of Horticulture, East Lansing, Ph.D. Dissertation.

Tollenaar, M. and A. Aguilera. 1992. Radiation use efficiency of an old and a new maize hybrid. Agronomy 84:536-541, doi: 10.2134/ agronj1992.00021962008400030033x.

U.S Census Bureau. 2020. U.S. Import and Export Merchandise trade statistics, 060210; generated by Mary Vargo; using data.census.gov; https:// data.census.gov/cedsci/ (30 Nov. 2020).
Wegulo, S.N., S.T. Koike, M. Vilchez, and P. Santos. 2004. First report of downy mildew caused by Plasmopara obducens on impatiens in California. Plant Dis. 88:909, doi: 10.1094/ pdis.2004.88.8.909b.

Whipker, B.E. and I. McCall. 2000. Response of potted sunflower cultivars to daminozide foliar sprays and paclobutrazol drenches. HortTechnology 10:209-211, doi: 10.21273/horttech.10.1.209.

Will, E., J.E. Faust, and B.B. Burgoa. 1999. Comparison of container placement patterns for maximizing greenhouse space use. HortTechnology 9:432-435, doi: 10.21273/hortsci.32.3.479e. 